\title{
The Effect of Story Telling Method towards Kindergarten Teachers' English Speaking Skill and Motivation
}

\author{
Saridewi \\ Department of Early Childhood Education, \\ Faculty of Education Universitas Negeri Padang \\ Jl. Prof. Dr. Hamka, UNP Campus Air Tawar, \\ Padang, West Sumatera \\ saridewi@fip.unp.ac.id
}

\begin{abstract}
The objective of this study was to describe the effect of story telling method towards Kindergarten teachers' English speaking skill and motivation. Based on the objective above, the writer conducted quashy experiment research. The population was Kindergarten teachers in Padang city, West sumatera province-Indonesia. In determining sample of research, the writer used cluster sampling that is to get sample based on their cluster or group. Those kindergarten teachers were undergraduate learners at Early Childhood Education Study Program, Universitas Negeri Padang. Group A as experiment class while $B$ as control class. Next, the data were collected using pre-test and post-test, in form of oral proficiency test. To analyze the data, the writer used Anava $2 \times 4$ Designs. The result showed that story telling method can be applied as one of the alternative to improve the teachers' English speaking skill and motivation. From the research finding, it can be concluded that: (1) there is differentiation in study result between experiment and control groups, (2) there is differentiation in pretest study result of high motivation learners' between experiment and control groups, (3) there is no differentiation in pre-test study result of low motivation learners' between experiment and control groups, (4) There is differentiation in post-test study result of high motivation learners' between experiment and control groups, and (5) there is differentiation in post-test study result of low motivation learners' between experiment and control groups.
\end{abstract}

Keywords—story telling method; English speaking skill

\section{INTRODUCTION}

This template. There is today a growing interest in the teaching of Speaking English. Current methodology has attempted to bring it into line with the various developments in the teaching of speaking because English is used as medium of International communication. Through communication, people all over the world convey information, share ideas, establish and maintain social relation among others. For instance, someone gives a point of view, discusses a situation, or even argues question; his/ her ability to communicate effectively will determine his/ her level of success. In conclusion, knowledge of the principles of public speaking is essential to develop speaking ability.
Some distinct forms of public speaking are debating, discussing, story telling, and delivering speech-where there is particular emphasis on constructing argument, defending, and describing it in conjuction with others. According to some experts, debate, discussion, story telling, and speech are good to encourage the learners to speak English during teaching and learning process - the learners are free to express their own idea, give opinions and argumentations - which are supported by current references. There are some characteristics of a successfull speaking activity in the classroom as follows: (1) learners talk a lot, (2) participation is even, (3) motivation is high, and (4) language is of an acceptable level [1]. In relation to those characteristics, story telling method can be applied to encourage the learners' speaking skill.

Based on the researcher's observation, there are still some problems found in the teaching of speaking English that Kindergarten teachers in Padang faced difficulty in speaking English fluently - afraid, shy, nervous, and doubt - to say something in front of audience. As a result, they tend to keep silent - no response - towards what is being discussed.

The second problem was the tecnique that the lecturer used in teaching English speaking; it made the English class neither communicative nor interactive, so most of learners were passive, only of them speak during the class. They only memorized or even took a note before they presented what they were going to say nest in discussion class. This technique seem to be monotonous and unable to encourage the learners' speaking ability since they practice their English only to present the topic that will be discussed in their group.

And the last problem that was motivation as the instrinsic factor. According to some experts, motivation is one of the instrinsic factors in someone succeed in English. If someone was eager to learn English for a reason and did something because he/ she wanted to do it, it is called instrinsic motivation. On contrast, if someone learned English due to some forces, punishment, and reward, they belong to extrinsic motivation.

The writer was interested in conducting this research because the fact shows that Kindergarten Teachers in Padang still passive and low English speaking skill. Based on the 
background of the problem, the objectives of this study were: (1) to find out the differentiation in study result between experiment and control groups, (2) to identify the differentiation in pre-test study result of high motivation learners' between experiment and control groups, (3) to know the differentiation in pre-test study result of low motivation learners' between experiment and control groups, (4) to clarify the differentiation in post-test study result of high motivation learners' between experiment and control groups, and (5) to justify the differentiation in post-test study result of low motivation learners' between experiment and control groups.

\section{The Nature of Speaking}

Speaking is the ability to speak and communicate to others. Someone ability to communicate effectively will determine his/ her level of success. According to Vassallo [2] there are four mechanics of speaking such as:

1) Voice consist of vocal energy, pitch, range, level, and delivery rate

2) Breathing control consist of Clavicular breathing (from the top of the chest), Throracic breathing (normal chest breathing), Abdominal or Diaphragmatic breathing (type for public speaking because the air quantity is maximized)

3) Diction or word-choice

4) Silence - the sound that refreshes

From the quotation above, the writer take a conclusion that before the speaker presents what he/ she is going to say, the speaker must realize the following points: (1) the situation "formal or informal", (2) the audience "to whom the speaker speak", (3) a brief outline "the topic what will be delivered by the speaker", and (4) mechanics of speaking "voice, breathing control, diction or word-choice, also silence-the sound that refreshes"

Furthermore, speaking deals with correct vocabulary, grammar, pronunciation, and knowledge about the topics that will be talked about. Harris, 1998 in [3] divides speaking ability into five components, they are:

1) Pronunciation includes vowel, consonants, and intonation

2) Grammar is the ability to use sentences in general and structure use

3) Vocabulary relates to the right and appropriate use of words

4) Fluency is the ease and the speed of the flow of the speech

5) Comprehension is a subject to respond to speech as well as to initiate it

Language learners need to recognize that speaking involves three areas of knowledge:

1) Mechanic (pronunciation, grammar, and vocabulary)

2) Fuctions (transaction and interaction)

3) Social and cultural rules and norms
To sum up, there are four main areas where speaker can find common ground with listeners: common needs, shared interests, mutual concerns, and same experiences. In addition, the speaker should select-appropriate topic, purpose, and central ideas - as the main points to persuade audience.

Current research done by Yakuzi [4] there are three classification of speaking performances as presented in Table I below.

Table 1. Speaking Performance

\begin{tabular}{|c|c|c|c|}
\hline No. & $\begin{array}{l}\text { Not so } \\
\text { effective }\end{array}$ & Fairly effective & Effective \\
\hline 1. & $\begin{array}{l}\text { Do not speak } \\
\text { clearly }\end{array}$ & Speak clearly & $\begin{array}{l}\text { Speak more } \\
\text { clearly }\end{array}$ \\
\hline 2. & $\begin{array}{l}\text { Mistake over } \\
\text { words to much }\end{array}$ & $\begin{array}{l}\text { Speak in little } \\
\text { mistake }\end{array}$ & $\begin{array}{l}\text { Speak in a } \\
\text { flowing way }\end{array}$ \\
\hline 3. & $\begin{array}{l}\text { Do not speak at } \\
\text { the right speed }\end{array}$ & $\begin{array}{l}\text { Sometimes } \\
\text { speak at the right } \\
\text { speed }\end{array}$ & $\begin{array}{l}\text { Speak at the } \\
\text { right speed }\end{array}$ \\
\hline 4. & $\begin{array}{l}\text { Do not know } \\
\text { what he/ she is } \\
\text { talking about }\end{array}$ & $\begin{array}{l}\text { A little bit know } \\
\text { and understand } \\
\text { what he/ she is } \\
\text { talking about }\end{array}$ & $\begin{array}{l}\text { Know what he/ } \\
\text { she is talking } \\
\text { about }\end{array}$ \\
\hline 5. & $\begin{array}{l}\text { Do not } \\
\text { organize }\end{array}$ & Near organize & Well organize \\
\hline 6. & $\begin{array}{l}\text { Lost eye } \\
\text { contact }\end{array}$ & $\begin{array}{l}\text { Keep up eye } \\
\text { contact fairly } \\
\text { well }\end{array}$ & $\begin{array}{l}\text { Keep up eye } \\
\text { contact } \\
\text { throughout }\end{array}$ \\
\hline 7. & $\begin{array}{l}\text { Do not use a } \\
\text { lively face }\end{array}$ & $\begin{array}{l}\text { Sometimes use a } \\
\text { lively face }\end{array}$ & $\begin{array}{l}\text { Used a lively } \\
\text { face }\end{array}$ \\
\hline 8. & $\begin{array}{l}\text { Shifted about a } \\
\text { lot }\end{array}$ & $\begin{array}{l}\text { A little stood } \\
\text { firmly }\end{array}$ & Stood firmly \\
\hline 9. & $\begin{array}{l}\text { Do not really } \\
\text { seemed really } \\
\text { confident \& } \\
\text { interested }\end{array}$ & $\begin{array}{l}\text { Seemed fairly } \\
\text { confident \& } \\
\text { interested }\end{array}$ & $\begin{array}{l}\text { Seemed really } \\
\text { confident \& } \\
\text { interested }\end{array}$ \\
\hline 10. & $\begin{array}{l}\text { Do not really } \\
\text { reached his/ } \\
\text { her audience }\end{array}$ & $\begin{array}{l}\text { reached his/ her } \\
\text { audience fairly } \\
\text { well }\end{array}$ & $\begin{array}{l}\text { Really reach his/ } \\
\text { her audience }\end{array}$ \\
\hline
\end{tabular}

In summary, an effective speaking performance is needed by the speaker to determine his/ her success in conveying information and ideas to audience. The speaker must deliver an up-to-date informations, examples, and familiar descriptions to audience. These combinations are needed by speaker to persuade listeners, especially when he/ she is speaking to create good communication.

\section{Kinds of Motivation}

In relation to the teaching and learning process, Brown [5] says that motivation is one of the most important factors in Speaking English. Motivation means having a real purpose in learning English, or really wanting to learn English for a reason. Furthermore, he adds there are two kinds of motivation (internal and external motivations) 
According to Sardiman [6], there are three functions of motivation a s follows: (1) encouraging human to do something, (2) giving direction to the human goal, (3) selecting human behavior. In conclusion, motivation is strong drive to encourage someone to learn something.

Huit [7] also explains in general that motivation can be categorized as either extrinsic or instinsic. Instinsic sources and corresponding theories can be further subcategorized as either body/ physial, mind/ mental (cognitive, affective, conative) or transpersonal/ spiritual.

Other research sources written by Ellen [8] says that there are two kinds of students in term of motivation-students with high and low motivations. First, characteristics of students with high motivation are:

1) understand how succeeding in college fits with their own personal, academic, social, and occupational goals,

2) focus on goals to help them stay committed to putting the effort and doing what is necessary to benefit from college,

3) are more likely to work hard at participating in their classes and at learning the material presented,

4) are more likely to keep working in the face of difficulties when trying to understand a concept or complete a long, complex assignment,

5) tend to see success as a function of their effort,

6) understand that there are factors they cannot control (e.g. , the type of test or assignment given), and focus on the factors that are controllable (e.g., how much time, energy, and effort they can apply to the work) are:

Second, characteristics of students with low motivation

1) usually not clear about how college fits with their own personal, academic, social, and occupational goals,

2) may easily distracted when listening to their teacher or completing assignments on which they are working,

3) may find it difficult to get started on their homework or other class projects,

4) may not put much effort in assignments and they may find it difficult to start or complete homework,

5) may find it difficult to participate in class and to stay on learning the information being taught,

6) are more likely to blame someone or something else for their poor performance,

7) are often less successful because they may not accepte responsibility for their performance.

From the explanation above, it can be concluded that motivation is very important because motivation is about accepting responsibility for performing the everyday behaviors associated with college, such as reading textbooks, preparing for class, finishing assignments on time, and studying for exams.

\section{Storytelling Method}

Preparation is needed, especially when someone apply storytelling method-choose the type of story, prepare the place, and present the story. According to Tampubolon [9] the preparation of story telling consist of: choosing and sorting the story material, managing the classroom and place for story teller, and choosing delivering strategy. Some techniques that suggested as follows

1) direct reading from story book

2) deliver story based on the story book illustration

3) read some falktale

4) use flannel and dool when deliver story

5) dramatize a story

6) use fingers during storytelling

\section{METHOD}

The study was quashy experiment by using pre-test and post-test control group design, independent variables were story telling (X1) and Conventional (X2) techniques, while dependent variables were the students' speaking skill (Y1) and motivation (Y2). In doing research, the writer took the following steps: (1) finding out the research problem to be investigated before formulating the title; (2) reading relevant literature, which support the topic of this research; (3) writing research design; (4) preparing the research instruments in form of questionnaire to identify the students' motivation. Then, pre-test and post-test that is given to both groups were oral proficiency test, conducts to Balai Bahasa (language center); (5) giving pre-test to both groups (Experiment and control groups); (6) classifying the studets' into two classificationshigh and low motivation students'-by giving series of questionnaires, then the writer arranged the students based on their score; (7) giving treatment to experimental group by applying English debate technique; (8) giving post-test to both groups (Experiment and control groups); (9) getting the data; (10) analyzing the data; (11) drawing conclusions; (12) proposing suggestions; (13) writing the research report. To analyze the data, the writer used Anava 2x4 Designs.

\section{RESULT AND DISCUSSION}

In this study, the hypothesis testing used Anava $2 \times 4$ designs to justify (1) the differentiation in study result between experiment and control groups, (2) differentiation in pre-test study result of high motivation learners' between experiment and control groups, (3) differentiation in pre-test study result of low motivation learners' between experiment and control groups, (4) differentiation in post-test study result of high motivation learners' between experiment and control groups, and (5) differentiation in post-test study result of low motivation learners' between experiment and control groups. 


\section{The First Hypothesis}

H0:There is no differentiation in study result between experiment and control groups

$\mathrm{H} 1$ :There is differentiation in study result between experiment and control groups

Table 2. Result of Anava 2x4 Designs

\begin{tabular}{lllllll}
\hline JKP & JKG & JKP+JKG & S12 & S22 & Fh & Ft \\
\hline 557.5 & 100.28 & 657.78 & 185.83 & 1.39 & 133.69 & 2.76 \\
\hline
\end{tabular}

Since $\mathrm{Fh}>\mathrm{Ft} 0.05$, H0 was rejected and $\mathrm{H} 1$ was accepted. It means that there is differentiation in study result between experiment and control groups.

\section{The Second Hypothesis}

H0: There is no differentiation in pre-test study result of high motivation learners' between experiment and control groups

H1: There is differentiation in pre-test study result of high motivation learners'between experiment and control groups

Table 3. Result of Anava 2x4 Designs

\begin{tabular}{llllll}
\hline S & S $\alpha$ & XA.1.1.B1 & XA.2.1.B1 & nA.1.1.B1 & nA.2.1.B1 \\
\hline $\mathbf{4}$ & 2.87 & 10.73 & 9.21 & 19 & 19 \\
\hline
\end{tabular}

Since $\mathrm{S}>\mathrm{S} \alpha, \mathrm{H} 0$ was rejected and $\mathrm{H} 1$ was accepted. It means that there is differentiation in pre-test study result of high motivation learners' between experiment and control groups.

The Third Hypothesis

H0: There is no differentiation in pre-test study result of low motivation learners' between experiment and control groups

H1: There is differentiation in pre-test study result of low motivation learners'between experiment and control groups

Table 4. Result of Anava 2x4 Designs
Table 5. Result of Anava 2x4 Designs

\begin{tabular}{llllll}
\hline $\mathbf{S}$ & $\mathbf{S \alpha}$ & $\mathbf{X A . 1 . 1 . B 2}$ & XA.2.1.B2 & nA.1.1.B2 & nA.2.1.B2 \\
\hline $\mathbf{0 . 7 5}$ & 2.76 & 6.54 & 6.33 & 24 & 21 \\
\hline
\end{tabular}

Since $\mathrm{S}<\mathrm{S} \alpha, \mathrm{H} 0$ was accepted and $\mathrm{H} 1$ was rejected. It means that there is no differentiation in post-test study result of high motivation learners' between experiment and control groups.

The Fifth Hypothesis

H0: There is no differentiation in post-test study result of low motivation learners' between experiment and control groups

H1: There is differentiation in post-test study result of low motivation learners' between experiment and control groups

Table 6. Result of Anava 2x4 Designs

\begin{tabular}{llllll}
\hline S & Sa & XA.1.2.B2 & XA.2.2.B2 & nA.1.2.B2 & nA.2.2.B2 \\
\hline $\mathbf{1 8 . 8 7}$ & 2.76 & 12.16 & 6.90 & 24 & 21 \\
\hline
\end{tabular}

Since $\mathrm{S}>\mathrm{S} \alpha, \mathrm{H} 0$ was rejected and $\mathrm{H} 1$ was accepted. It means that there is differentiation in post-test study result of low motivation learners' between experiment and control groups.

Based on the research finding, the result showed that story telling method can be applied as one of the alternative to improve the teachers' English speaking skill and motivation. As stated by Ur (2000:120) that there are some characteristics of a successfull speaking activity in the classroom as follows: (1) learners talk a lot, (2) participation is even, (3) motivation is high, and (4) language is of an acceptable level.

\section{CONCLUSIONS}

From the research finding, it can be concluded that: (1) there is differentiation in study result between experiment and control groups, (2) there is differentiation in pre-test study result of high motivation learners' between experiment and

\begin{tabular}{llllll}
\hline $\mathrm{S}$ & $\mathrm{S \alpha}$ & $\mathbf{X A . 1 . 2 . B 1}$ & $\mathbf{X A . 2 . 2 . B 1}$ & $\mathbf{n A . 1 . 2 . B 1}$ & nA.2.2.0B1 \\
\hline $\mathbf{1 4 . 1 0}$ & 2.87 & 16.36 & 11.00 & 19 & 19 \\
\hline
\end{tabular}

Since $\mathrm{S}>\mathrm{S} \alpha, \mathrm{H} 0$ was rejected and $\mathrm{H} 1$ was accepted. It means that there is differentiation in pre-test study result of low motivation learners' between experiment and control groups.

\section{The Fourth Hypothesis}

H0: There is no differentiation in post-test study result of high motivation learners' between experiment and control groups

H1: There is differentiation in post-test study result of high motivation learners' between experiment and control groups $\mathbf{1}^{\text {control groups, }}$ (3) there is no differentiation in pre-test study result of low motivation learners' between experiment and control groups, (4) There is differentiation in post-test study result of high motivation learners' between experiment and control groups, and (5) there is differentiation in post-test study result of low motivation learners' between experiment and control groups.

There are two implications in this study, first, the use of story telling method is one of the alternatives that can be applied to minimize the students' speaking problem and increase the learners' motivation; especially for low motivation learners'. The last, the lecturer must choose and combine their teaching materials to make the process of teaching and learning more enjoyable, effective, and efficient; especially in speaking class. 


\section{References}

[1] Penny, A Course in Language Teaching. New York: Cambridge University Press, 2000.

[2] Vassallo and Wanda, Speaking with Confidence: A Guide for Public Speakers. Kuala Lumpur: Golden Books Centre, 2004.

[3] Yassin and Anas. (2000, An Analysis of Factors influencing the Students' Speaking Ability.

[4] Yakuzi. (2006, Speaking Performance.

[5] Brown and H. Douglas, Strategies for Success: A Practical Guide to Learning English. New York: Longman, 2002.

[6] Sardiman, Interaksi dan Motivasi Belajar Mengajar. Jakarta: PT. Raja Grafindo Persada, 2006.

[7] Huit. (2006, Motivation to Learn: An Overview.

[8] Ellen and C. Weinstein. (2006, Learners' motivation.

[9] Tampubolon, Mengembangkan Minat dan Kebiasaan Membaca pada Anak. Bandung: Angkasa 1991. 